Результати дисертаційних та науково-дослідних робіт

УДК: 616.35-007.271:616.832-007.1:616.6039-039.76-053.2

\section{I.O. Македонський}

К3 «Дніпропетровська міська клінічна лікарня № 3. ім. проф. М.Ф.Руднєва (м. Дніпропетровськ, Україна)
ДИФЕРЕНЦЙОВАНИЙ ПІДХІД ДО

ЛІКУВАННЯ НЕЙРОГЕННИХ ПОРУШЕНЬ

СЕЧОВИПУСКАННЯ У ПАЦІЄНТІВ

3 АНОРЕКТАЛЬНИМИ АНОМАЛІЯМИ ТА ІЗ СУПУТНЬОЮ ВНУТРІШНЬОХРЕБЕТНОЮ ПАТОЛОГІЄЮ
Ключові слова: аноректальні вади, мієлодисплазія, хірургічна корекиія, медична абілітація.
Резюме. Проведений аналіз результатів лікування 48 дітей з аноректальними аномаліями у поєднанні з мієлодисплазією з наявністю нейрогенних порушень сечовипускання. За допомогою ультразвукового, рентгенологічного, уродинамічного методів обстеження розроблені критеріі диференційованого підходу до лікування. Запропонований алгоритм лікування, який включає періодичну стерильну катетеризацію сечового міхура, фармакологічну терапію, різноманітні види хірургічних втручань.

\section{Вступ}

Аноректальні аномалії у поєднанні з вадами розвитку крижів, мієлодісплазією належать до найтяжчих множинних вад розвитку та включають вади розвитку аноректальної зони, хребта, крижів, спинного мозку [1,3]. В структурі вроджених вад розвитку аноректальні аномаліі (APA) займають провідне місце. Частота цієї патології коливається у межах 1 на 3500 - 4500 пологів [1,4]. Найчастіше аномалії розвитку хребта поєднуються з вадами розвитку сечостатевої системи $(21,7 \%)$ та аноректальними вадами $(48,8 \%)$ [3]. У групі дітей 3 аноректальними вадами у поєднанні з аномаліями крижів часто виникають значні урологічні проблеми $[2,5,6]$. Як і в пацієнтів з менінгомієлоцеле, захворюваність у цій групі пацієнтів може бути значно знижена завдяки рутинному скринінгу усіх новонароджених 3 AРА та чітким рекомендаціям щодо відповідних терапевтичних або хірургічних заходів. За даними провідних світових центрів корекції вроджених вад, летальність у групі дітей $з$ високими формами АРА склала $6,4 \%, 3$ низькими - 1,1\%. Причиною загибелі дітей стала гостра ниркова недостатність $[3,4]$. Значно більшим залишається відсоток ранньої інвалідності $(75,0 \%)$ та зниження якості життя $(92.0 \%)$ [7,8]. На сьогодні питання виявлення функціональних урологічних проблем у новонароджених 3 аноректальними вадами, рекомендації щодо своєчасної діагностики та лікування цих пацієнтів розроблені недостатньо $[2,7,9]$.

Метою нашого дослідження було підвищення ефективності лікування хворих 3 аноректальними аномаліями у поєднанні 3 мієлодісплазією, попередження та раннє виявлення порушення функції нирок шляхом розробки та впровадження нової схеми медичної абілітації, спрямованої на досягнення утримання сечі та калу до початку відвідування дитиною дитячого дошкільного закладу та початкової школи.

\section{Матеріали та методи}

Проведений аналіз результатів лікування 48 дітей $з$ аноректальними аномаліями у поєднанні 3 вадами розвитку крижів, мієлодисплазією з наявністю нейрогенних порушень сечовипускання, що лікувалися у хірургічному відділенні Дніпропетровської міської дитячої лікарні №3 ім. проф. М.Ф.Руднєва за період 1990 - 2011 pр. Усі діти з аноректальними вадами пройшли оглядову рентгенографію хребта у передньо-задній та боковій проекціях. При цьому звертали увагу на кількість та форму тіл хребців, крижів. Нижні відділи хребта вивчалися на наявність зрощення, деформацій та симетричність тіла хребця. Наявність кісткових дефектів або асиметрії вважали ознаками люмбо-сакральної дисплазії. Якщо на оглядовій рентгенограмі виявляли аномалії, виконували УЗД хребта для виявлення супутньої внутрішньохребтової патології.

Для ранньої діагностики порушень сечовипускання ми запровадили 4-х годинне спостереження сечовипускання у дітей раннього віку як простий, чутливий, неінвазивний спосіб діагностики. Вказане обстеження проведено 44 дітям 3 AРА (26 дівчат, 18 хлопців) віком 1,8-12,3 місяців. Спостереження проводили батьки дитини під контролем кваліфікованої медсестри. Після годування дитини проводили ультразвукове вимірювання об'єму сечового міхура (CM) та об’єму виділеної сечі шляхом зважування памперсу. Далі кожні 10 хвилин проводили перевірку памперсу та його зважування. Наявність залишків сечі визначали за допомогою УЗД (лінійний датчик 7,5 MHz). В результаті такого 4-х годинного спостереження ми отримували інформацію про кількість сечовипускань, об' $\mathrm{M}$ сечі за одне сечовипускання, об'єм залишкової 
сечі, функціональний об'єм СМ (найбільший об'єм виділеної сечі за один раз плюс об'єм залишкової сечі). Результати оформляли у вигляді протоколу спостереження з відміткою про сон, харчування та крик дитини.

Уродинамічні дослідження проводили 3 використанням стандартної цистометрії з повільною інфузією рідини (4-12 мл хв) через 9 Fr двопросвітний уретральний катетер. Дослідження виконували без призначення седативних ліків. Тиск підтікання рідини (ТП) більший за 40 см водяного стовпа вважали підвищеним. Дані уродинамічних досліджень зіставляли 3 даними клінічного та рентгенологічного дослідження. Уродинамічні дослідження використовували як основні методи дослідження для класифікації нейрогенних дисфункцій та визначення подальшої тактики лікування. Усіх пацієнти з АРА у поєднанні з мієлодісплазією (МД) поділено на 2 основні групи у залежності від внутрішньоміхурового тиску (ВМТ).

\section{Результати та їх обговорення}

Проведений аналіз результатів лікування 48 дітей з АРА у поєднанні з вадами розвитку крижів, МД з наявністю нейрогенних порушень сечовипускання (НПС). За основний об'єктивний критерій вибору терапії в цій групі були обрані уродинамічні дані (УДД). У 19 (39,6\%) пацієнтів цієї групи спостерігали комбіноване нетримання сечі та калу.

Усі пацієнти 3 АРА у поєднанні з МД були поділені на 2 основні групи: група А - діти 3 низьким BMT (n= 22), група Б - діти 3 високим ВMT $(\mathrm{n}=26)$. До групи А було віднесено 22 дитини віком від 3 до 15 років. Ці пацієнти мали неконтрольовані періодичні підтікання сечі. Підтікання сечі виявлялося випадково, тривалість сухого періоду варіювала від кількох хвилин до кількох годин. У 6-х дітей підтікання сечі збільшувалося при кашлі, сміху, підвищенні фізичної активності. Таким чином, ці діти страждали на нетримання сечі. У 10 дітей був високий об’єм резидуальної, залишкової сечі від 50 до 100 мл. У 2 виявлене значне розширення верхніх сечових шляхів (гідронефроз), у одного $з$ них приводом цього був коралоподібний камінь у нирці. У 7 дітей виявлений везіко-уретральний рефлюкс (ВУР) I ст, у 2-х був ВУР 4 ст. У всіх цих випадках при ультразвуковому обстеженні відмічено потовщення стінки CM. Уродинамічне дослідження виявляло низький або нормальний ВМТ, який не перевищував 40 см. вод. ст. та великий об'єм СМ (200 мл та більше).

У групі дітей 3 низьким ВМТ тиском виділено 2 підгрупи :

A1. Діти 3 низьким ВМТ (30-40 см.вод.ст) та слабим сфінктером і м'язами тазового дна (МТД) $(\mathrm{n}=12)$.

А2. Діти з низьким ВМТ (30-40 см.вод.ст) та добре розвинутими сфінктерами і м'язами тазового дна $(\mathrm{n}=10)$.

Ступінь розвинення МТД визначали під час уродинамічного обстеження 3 додатковою ЕМГ. Лікування пацієнтів підгрупи А1 (табл.1) складалося 3:

1) призначення альфа-симпатомиметиків для підвищення активності сфінктерів та забезпечення утримання сечі,

2) проведенням програми електростимуляції МТД,

3) впровадження програми примусового сечовипускання, або проведення періодичної стерильної катетеризації СМ кожні 3 години 3 нічним інтервалом.

Інфекція сечової системи не зустрічалася в цій групі хворих, везіко-уретеральний рефлюкс I - П ст. не виявлявся у 2-х пацієнтів після 6 місяців лікування. Пацієнти підгрупи А2 лікувалися із впровадженням програми примусового сечовипускання (або проведенням періодичної стерільної кататеризації (M) та тренуваннями методом Б33. Виконання цих процедур приводило до досягнення "сухого" періоду на протязі кількох годин, зникнення проявів рефлюксу у 3 із 7 дітей 3 рефлюксом I ст. та переходом 3 IV ст.до Шст. у однієї дитини.

У групу Б були включені діти з високим

Таблиця 1

Лікувальна тактика у пацієнтів з низьким внутрішньоміхуровим тиском

\begin{tabular}{|c|c|c|}
\hline Підгрупи пацієнтів (n=22) & $\begin{array}{l}\text { А1 - кількість пацієнтів } 3 \\
\text { слабкою активністю сфрінктера }\end{array}$ & $\begin{array}{l}\text { А2 - кількість пацієнтів } 3 \\
\text { доброю активністю сфрінктера }\end{array}$ \\
\hline $\begin{array}{l}\text { Низький внутрішньоміхуровий тиск } \\
\text { (30-40 см .вод. ст.) }\end{array}$ & 12 & 10 \\
\hline Лікування & $\begin{array}{l}\text { 1.Примусове сечовипускання (або } \\
\text { періодична стерильна катетериза- } \\
\text { ція ПСК), } \\
\text { 2.Альфа-симпатоміметики } \\
\text { 3. Електростимуляція МТД. }\end{array}$ & $\begin{array}{l}\text { 1.Примусове сечовипускання } \\
\text { (або періодична стерильна кате- } \\
\text { теризація ПСК), } \\
\text { 2.Тренування методом біозворот- } \\
\text { нього зв'язку (БЗ3). }\end{array}$ \\
\hline
\end{tabular}


ВМТ (n=26). Усі діти цієї групи неконтрольовано випускали сечу та мали зниження чутливості СМ. Підтікання спостерігали поміж “сухих" періодів, постійне підтікання спостерігали випадково.

У цій групі виявлено 4 дітей з гідронефрозом та мегауретером.. Везікоуретеральний рефлюкс виявлений у 20 дітей: 2 ст - у 9 дітей, 3 ст - у 6, 4 ст - у 3,5 ст - у 2. У всіх дітей цієї групи СМ був великий, з ознаками детрузорної гіпертрофії та псевдодивертикулами. Уродинамічні дослідження виявили значне підвищення внутрішньоміхурового тиску від 60 до 200 см.вод.ст. Лікувальна стратегія в цій групі була спрямована на зниження підвищеного внутрішньоміхурового тиску за рахунок використання антихолінергетиків або хірургічним шляхом (везікостомія, аутоцистопластика, ентероцистопластика).

Вибір способу залежав від декількох факторів: результатів уродинамічного дослідження (об'єм СМ, значення тиску, стану сфінктеру); стану верхніх сечових шляхів; віку дитини; результатів попереднього лікування.

У цій групі також було виділено 2 підгрупи згідно тих самих критеріїв:

Б1- діти 3 підвищеним ВМТ, слабким сфінктером та м’язами тазового дна $(\mathrm{n}=11),($ табл.2).

Таблиця 2

Лікувальна тактика пацієнтів 3 високим внутрішньоміхуровим тиском та слабким сорінктерно-м'язовим апаратом (Б1)

\begin{tabular}{|c|c|c|c|c|}
\hline \multirow{2}{*}{ Підгрупа Б $1(\mathrm{n}=11)$} & & $\begin{array}{c}\text { Примусове се- } \\
\text { чопускання }+ \\
\text { Дітропан }\end{array}$ & $\begin{array}{c}\text { Аутоцисто- } \\
\text { пластика }\end{array}$ & $\begin{array}{c}\text { Ентеро-цисто- } \\
\text { пластика. }\end{array}$ \\
\hline \multirow{2}{*}{$\begin{array}{c}\text { Високий ВМТ 60-200 } \\
\text { см.вод.ст. та слабкий } \\
\text { сфрінктерно-м'язовий } \\
\text { апарат }\end{array}$} & Петлева процедура & - & 2 & 1 \\
\cline { 2 - 5 } & Пластика шийки СМ & 5 & 1 & - \\
\cline { 2 - 5 } & Електростимуляція МТД & 7 & - & - \\
\hline
\end{tabular}

Ці діти були вологими майже увесь час, або мали короткі, до 10-20 хвилин, сухі періоди.

Б 2 - діти 3 підвищеним ВМТ $з$ гарною активністю сфінктера та м'язів тазового дна $(\mathrm{n}=15)$ (табл.3).

У цій групі в одного пацієнта відмічено ушкодження верхніх сечових шляхів (ниркова недостатність), яка була викликана двобічним везіко-уретеральним рефлюксом IV ст. Лікування дітей цієї групи було спрямоване на зниження ВМТ, який був значно підвищеним, всупереч слабкості сфінктера. Це завдання досягалося наступними методами: призначенням антихолінергетиків (дітропан), аутоцистопластикою або ентероцистопластикою, проведенням БЗ3 тренінгу.

Незважаючи на явне збільшення об'єму СМ у всіх пацієнтів та зниження ВМТ, вдавалося досягти лише часткового покращення функції утримання сечі. Подальше лікування було спрямовано на поліпшення сфінктерної функції та включало медикаментозне лікування (іміпрамін), формування фасціальної петлі в зоні шийки СМ, пластику шийки СМ (табл.2).

Призначення антихолінергічних препаратів (дітропан) 7 дітям 3 об'ємом СМ більше за 100 мл та 3 відсутніми змінами у верхніх сечових шляхах не призвело до поліпшення урологічного стану. У 5 випадках було виконано фасціальну петлю, у 2 - пластику шийки СМ 3 подальшим проведенням тренувань методом Б33. У 3 пацієнтів з високим ВМТ та об'ємом СМ більше за 150-200 мл для зниження тиску була виконана аутоцистопластика. Один з них потребував кур- су лікування іміпраміном у зв'язку з підвищенням активності внутрішнього сфінктера, одній дитині проведено формування фасціальної петлі. Оперативне збільшення об'єму СМ шляхом ентероцистопластики проведено у 1 дитини, яка потім потребувала лікування іміпраміном. У підгрупі Б2 спостерігалася задовільна функція утримання сечі, що було пов'язано з гарною активністю зовнішнього уретрального сфінктеру, який посилював негативний вплив підвищеного тиску на верхні сечові шляхи.

Ушкодження верхніх сечових шляхів найбільш часто зустрічалося в цій групі. Фармакологічна терапія використовувалася для зниження ВМТ у 15 пацієнтів. Ми використовували наступні критерії для застосовування антихолінергічних препаратів: об'єм СМ більше 100 мл; відсутність, або початкові зміни верхніх сечових шляхів; вік більше 1 року; зміни верхніх сечових шляхів - дають змогу очікувати ефект від медикаментозної терапії.

Медикаментозна терапія була проведена 15 хворим, які відповідали зазначеним критеріям. Вік пацієнтів був у межах 3-15 років. Гідронефротична трансформація нирок та сечоводів спостерігалася у 4 пацієнтів, 10 дітей мали ВУР ( ст. П- 3, ст. Ш- 3, ст. IV- 4 випадки). Усі ці пацієнти отримували антихолінергічні препарати (оксібутінін, дітропан) для підвищення об’єму CM та зниження ВМТ завдяки їх антіхолінергічному ефекту та прямій релаксаційній дії на детрузор. Медикаментозну терапію доповнюва- 
ли тренуваннями методом Б33, програмою примусового сечовипускання (або ПСК). Всі ці діти починали утримувати сечу на період 3-4 годин після вказаної терапії. Спостерігалося зниження розширення верхніх сечових шляхів у всіх 4 пацієнтів, зникнення ВУР ст2 у 5 та зменшення ступеня ВУР з IV до III ступеня у 3 пацієнтів. Ці діти були оперовані з приводу ВУР через 3 місяці після закінчення лікування. У 2-х пацієнтів не спостерігали змін у ВМТ та об'ємі СМ. У цих випадках виконували аутоцистопластику (табл.3).

П’ять пацієнтів були толерантні до фармакологічної терапії. Використовували три типи хірургічних втручань для зниження ВМТ та збільшення об’єму СМ. Вибір способу залежав від

Таблиця 3

\section{Лікувальна тактика у пацієнтів з високим внутрішньоміхуровим тиском} та гарною м'язово-сфінктерною активністю (підгрупа Б2)

\begin{tabular}{|c|c|c|c|c|c|c|c|c|}
\hline \multirow{2}{*}{$\begin{array}{c}\text { Пацієнти } \\
(\mathrm{n}=15) / \\
\text { Характеристика СM }\end{array}$} & \multirow{2}{*}{$\begin{array}{l}\text { Вік } \\
(p)\end{array}$} & \multirow{2}{*}{$\begin{array}{c}\text { Кіль- } \\
\text { кість } \\
\text { пацієнтів }\end{array}$} & \multirow[b]{2}{*}{$\begin{array}{l}\text { Тільки } \\
\text { ПСК }\end{array}$} & \multirow{2}{*}{$\begin{array}{l}\text { Трену- } \\
\text { вання } \\
\text { Б33 }\end{array}$} & \multirow[b]{2}{*}{$\begin{array}{l}\text { Везіко- } \\
\text { стомія }\end{array}$} & \multicolumn{3}{|c|}{$\begin{array}{c}\text { Періодична стерильна } \\
\text { катетеризація }\end{array}$} \\
\hline & & & & & & Дітропан & $\begin{array}{l}\text { Аутоцис- } \\
\text { топлас- } \\
\text { тика }\end{array}$ & $\begin{array}{l}\text { Ентеро- } \\
\text { цисто- } \\
\text { пластика }\end{array}$ \\
\hline \multirow{3}{*}{$\begin{array}{c}\text { Високий ВМТ 60-200 } \\
\text { см.вод.ст з гарною } \\
\text { м'язово-сфрінктерною } \\
\text { активністю }\end{array}$} & $0-2$ & 5 & - & & 5 & - & - & - \\
\hline & $2-5$ & 7 & - & 3 & - & 5 & 2 & - \\
\hline & $5-10$ & 3 & - & 3 & - & 3 & 1 & 2 \\
\hline
\end{tabular}

віку пацієнта, наявності вентрікулярного шунта у випадках супутньої гідроцефалії, ступеня розширення верхніх сечових шляхів, ступеня ниркової недостатності.

Типи втручань були наступні: везікостомія, аутоцистопластика, ентероцистопластика. Везікостомія нами використовувалася у випадках: значного ушкодження верхніх та нижніх сечових шляхів; термінового розвантаження верхніх сечових шляхів та СМ; вік дитини 0-2 роки. Цей метод був застосований у 5 дітей віком від 3-х місяців до 2 років. Це були діти зі значними ураженнями верхніх сечових шляхів (гідронефроз, мегауретер, ВУР ст. V). Швидке поліпшення стану сечових шляхів після везікостомії спостерігали у всіх 5 дітей.

Критеріями для аутоцистопластики було: відносно великий об'єм СМ (більше за 100 мл); значне розширення верхніх сечових шляхів; наявність функціонуючого вентрикуло-перитонеального шунта; вік дитини $<2$ роки. Цей метод був застосований у 3 дітей віком від 3 до 13 років. Аутоцистопластика була обрана, переважно, для обмеження зони хірургічного втручання тільки позаочеревинним простором, особливо у дітей $з$ шунтованою гідроцефалією. Було відмічено, що аутоцистопластика збільшує об'єм СМ від 60 до 150-180 мл та знижує ВМТ у середньому на $65 \pm$ 7,6 см.вод.ст. Після проведення цієї процедури ці 3 дітей почали утримувати сечу до 3 години після ПСК. У 5 пацієнтів наступило покращення стану верхніх сечових шляхів. У однієї дитини залишилося розширення сечових шляхів та ВУР 4 ст. та безуспішне збільшення СМ.

Ентероцистопластика використовувалася у вигляді детубуляризованого сегменту здухвинної кишки 15-20 см. Показаннями для цієї операції вважали: малий об'єм СМ (менше за 100 мл); значні зміни верхніх та нижніх сечових шляхів; відсутність вентрикуло-перитонеального шунта; вік понад 5 років. Цей вид лікування використовували у 2 дітей віком 12 та 13 років для збільшення об'єму СМ та для зниження ВМТ. Гідронефротична трансформація виявлена у 1 дитини, у 1 був масивний ВУР 5 ст 3 нирковою недостатністю. Після використовування цього способу об'єм СМ збільшувався з 150 та 210 мл та знижував ВМТ на 70 та 85 см.вод.ст. Жодних електролітних порушень виявлено не було. Стан верхніх сечових шляхів покращився, а показники сечовини та креатиніну знизилися в обох пацієнтів. Усі діти мали 4-х годинний сухий період після застосування ПСК. Найбільш частим ускладненням після ентероцистопластики були інфекції сечових шляхів (2 випадки) та неможливість утримування сечі у зв'язку зі сфінктерною недостатністю (1 дитина). Стан верхніх сечових шляхів у оперованих дітей контролювався амбулаторно. Ультразвукове обстеження виконували через 1, 3 та 6 місяців 3 наступним щорічним контролем. Цистографія та урографія була проведена терміном через 1 рік.

\section{Висновки:}

1. Проведення комплексного урологічного обстеження пацієнтам з АРА у поєднанні з МД є обов'язковим. Уродинамічні дослідженння дають змогу визначити тип нейрогенних розладів сечового міхура, визначити тактику подальшого лікування та проводити контроль його ефектив- 
ності.

2. Тактика лікування нейрогенних розладів сечовипускання при АРА у поєднанні з МД повинна бути спрямована в першу чергу на захист верхніх сечових шляхів та попередження ушкодження нирок, у другу чергу - на формування функції утримання сечі.

3. Везікостомія є простим та безпечним методом захисту верніх сечових шляхів у новонароджених та дітей немовлячого віку.

4. Аутоцистопластика є ефективним спосо- бом зниження підвищеного внутрішньоміхурового тиску, сприяє значному збільшенню обсягу сечового міхура та покращенню показників уродинаміки.

5. Колоцистопластика $є$ ефективним методом збільшення обсягу сечового міхура у випадках малого його обсягу та підвищеного внутришньоміхурового тиску.

Перспектива подальших досліджень повинна бути спрямована на удосконалення фармакологічного та хірургічного лікування цієї групи хворих.

\section{Література}

1. Притыко А.Г. Диагностика и хирургическое лечение каудальных пороков развития позвоночника и спинного мозга у детей / А.Г. Притыко, И.В.Бурков, С.Н.Николаев -Ульяновск: Симбирская книга, 1999.- 96 с.

2. Bauer S.B. Neurogenic bladder dysfunction / S.B.Bauer//Pediatr .Clin.North Am.-1987.-N.34.- P.1121-1132.

3. Cuschieri A. Anorectal anomalies associated with or as part of other anomalies / A .Cuschieri // Am. J. Med. Genet. - 2002. -V. -110. -N.2. -P.122-130.

4. Endo M. Analysis of 1992 patients with anorectal malformations over the past two decades in Japan / M. Endo, A.Hayashi, M.Ishihara // J. Pediatric Surg.- 1999. -V. -34. -P. 435-441.

5. Macedo A. A continent catheterizable ileal based reservoir/A.Macedo, M. Srougi //BJU Int.- 2000.- N.-85., P.160-162.

6. Mingin G.C. Growth and metabolic consequences of bladder augmentation in children with myelomeningocele and bladder exstrophy. / G.C. Mingin, H.T.Nguyen, R.S. Mathias // Pediatrics.- 2002.- N.110.-P.1193-1198.

7. Nomura S. Augmentation ileocystoplasty in patients with neurogenic bladder due to spinal cord injury or spina bifida. / S. Nomura, T. Ishido, K.Tanaka. //Spinal Cord.-2002.-N 40.- P.30-33.

8. Sutherland R.S. Spinal dysraphism in children: an overview to prevent complications / R.S. Sutherland G.A. Mevorach, L.S. Baskin //Urology.- 1995.-N.46.-P.294-304.

9. Wu H. Neurogenic bladder dysfunction due to myelomeningocele / H. Wu, L.S. Baskin, B.A. Kogan //J.Urol.1997.-N. 157.- P.2295-2297.

\section{ДИФЕРЕНЦИРОВАННЫЙ ПОДХОД К ЛЕЧЕНИЮ НЕЙРОГЕННЫХ НАРУШЕНИЙ МОЧЕИСПУСКАНИЯ У ПАЦИЕНТОВ С АНОРЕКТАЛЬНЫМИ АНОМАЛИЯМИ И СОПУТСТВУЮЩЕЙ ВНУТРИПОЗВОНОЧНОЙ ПАТОЛОГИЕЙ}

\section{И.А. Македонский}

\author{
КУ «Днепропетровская городская \\ клиническая больница № 3 \\ им. проф. М.Ф.Руднева» \\ (г. Днепропетровск, Украина)
}

Резюме. Проведен анализ результатов лечения 48 детей с аноректальными аномалиями в сочетании с миелодисплазией с наличием нейрогенных расстройств мочеиспускания. С использованием ультразвукового, рентгенологического, уродинамического методов обследования разработаны критерии дифференцированного подхода к лечению. Предложен реабилитационный алгоритм, включающий периодическую стерильную катетеризацию мочевого пузыря, фармакологическую терапию, различные виды хирургических вмешательств.

Ключевые слова: аноректальные аномалии, миелодисплазия, хирургическая коррекция, медицинская абилитация.

\section{THE DIFFERENTIAL APPROACH TO TREATMENT OF NEUROGENIC DISORDERS OF URINATION IN PATIENT WITH ANORECTIC DISORDERS AND ACCOMPANYING INTRASPINAL PATHOLOGY}

Makedonskiy I.A.

\author{
CI «Dnepropetrovsk city \\ clinical hospital N3 \\ in honor of M.F.Rudneva», \\ (Dnepropetrovsk, Ukraine)
}

Summary. 48 patients with anorectalanorectic abnormalities combined with vertebral, myelodisplasia and neurogenic bladder were examined. With the use of X-ray, ultrasound, urodynamics thereCriteria for therapeutical and surgical treatment based on urodynamic data were proposed with the use of X-ray, ultrasound, urodynamics criteria for therapeutical and surgical treatment based on urodynamic data. Was proposed and carried out of using of different kinds of treatment, including periodic sterile catheterization of urine bladder, pharmacology and different kinds of surgical treatment, was proposed and carried out.

Keywords: abnormalities, myelodysplasia, sur-gical andsurgical and medical habilitation. 